ORIGINAL ARTICLE / ARTIGO ORIGINAL

Prevalence of physically active adolescents in Brazilian capitals: National Adolescent School-based Health Survey 2012 and 2015

\title{
Prevalência de adolescentes fisicamente ativos nas capitais brasileiras: Pesquisa Nacional de Saúde do Escolar 2012 e 2015
}

\author{
Luciano Antonacci Condessa',", Carlos Alex Soares ${ }^{\prime \prime \prime}$, Gregore Iven Mielke ${ }^{\mathrm{IV}}$, \\ Deborah Carvalho Maltav", Waleska Teixeira Caiaffa"
}

\begin{abstract}
Objective: To compare the prevalence of physically active adolescents living in Brazilian capitals, using 2012 and 2015 National Adolescent School-based Health Survey. Method: The sample consisted of 61,145 (2012) and 51,192 (2015) adolescents who were residents in 27 Brazilian capitals and were attending the 9th year of elementary school. The globally estimated physical activity indicator with the cutoff point of 300 minutes or more per week was used to determine the prevalence of physically active adolescents in both surveys. The prevalence rates were stratified by socio-demographic characteristics (gender, age, maternal schooling and skin color) and by capital of residency. Descriptive statistics were used for comparisons considering $95 \%$ confidence intervals. Results: The respective prevalence rates of physically active adolescents observed in $2012(21.0 \%$; $95 \%$ CI 20.3 $21.7)$ and $2015(20.7 \%$; $95 \%$ CI $20.1-21.3)$ were similar, independently of the sociodemographic characteristics. In considering the 27 capitals, a reduction in the prevalence of physically active adolescents from 2012 to 2015 was observed only in Belém. Conclusion: Overall, no changes in the prevalence of physically active adolescents residing in urban centers was observed from 2012 to 2015. These findings evidence the need for new public policies in order to enhance and promote the practice of physical activity among Brazilian adolescents, as well as the expansion of existing ones.
\end{abstract}

Keywords: Epidemiological surveys. Exercise. Adolescent health.

'Rio de Janeiro State Federal Institute of Education, Science and Technology - Itaperuna (RJ), Brazil.

"Urban Health Observatory of Belo Horizonte, School of Medicine, Universidade Federal de Minas Gerais - Belo Horizonte (MG), Brazil. "'Graduate Program in Physical Education, Universidade Federal de Pelotas - Pelotas (RS), Brazil.

IvGraduate Program in Epidemiology, Universidade Federal de Pelotas - Pelotas (RS), Brazil.

vDepartment of Maternal and Child Nursing and Public Health, School of Nursing, Universidade Federal de Minas Gerais Belo Horizonte (MG), Brazil.

Corresponding author: Luciano Antonacci Condessa. Avenida Professor Alfredo Balena, 190, 70 andar, Sala 730, Santa Efigênia, CEP: 30130-100, Belo Horizonte, MG, Brasil. E-mail: lucianoantonacci@yahoo.com.br

Conflict of interests: nothing to declare - Financial support: none. 
RESUMO: Objetivo: Comparar a prevalência de adolescentes fisicamente ativos, residentes nas capitais brasileiras, investigados nos inquéritos da Pesquisa Nacional de Saúde do Escolar de 2012 e 2015. Método: A amostra foi composta por 61.145 (2012) e 51.192 (2015) adolescentes das 27 capitais brasileiras, frequentes no nono ano do ensino fundamental. O indicador atividade física globalmente estimada com o ponto de corte de 300 minutos ou mais por semana foi utilizado para determinar a prevalência de adolescentes fisicamente ativos nos dois inquéritos. Em seguida, as prevalências foram estratificadas pelas características sociodemográficas (sexo, idade, escolaridade da mãe e cor da pele) e pelas capitais. Para a comparações das variáveis entre as duas edições da pesquisa foi utilizada estatística descritiva, com análise dos intervalos de confiança de 95\% (IC95\%). Resultados: As prevalências de adolescentes fisicamente ativos observadas em 2012 (21,0\%; IC95\% 20,3 - 21,7) e 2015 (20,7\%; IC95\% 20,1 - 21,3) foram similares, independente das características sociodemográficas analisadas. Dentre as 27 capitais analisadas, apenas em Belém foi verificada redução no percentual de adolescentes fisicamente ativos, entre 2012 e 2015. Conclusões: Não houve alteração da prevalência de adolescentes fisicamente ativos que residem nos centros urbanos entre 2012 e 2015, evidenciando a necessidade de novas políticas públicas para promover a prática de atividade física, assim como a expansão das já existentes.

Palavras-chave: Inquéritos epidemiológicos. Exercício. Saúde do adolescente.

\section{INTRODUCTION}

Physical activity, when practiced by children and adolescents, has been associated with an increase in aerobic capacity, muscular strength, and reduced risk of chronic noncommunicable diseases (NCD), such as obesity and diabetes ${ }^{1}$, with positive reflexes in adult life $\mathrm{e}^{2,3}$.

However, recent global estimates ${ }^{4,5}$ show that only 1 in 5 adolescents meets the recommendations of the World Health Organization $(\mathrm{WHO})^{6}$ for the practice of at least 60 daily minutes of physical activity with moderate to vigorous intensity. In Brazil, a series of epidemiological surveys, both local and national, have shown that the prevalence of physically active adolescents is low ${ }^{7-9}$.

The practice of physical activity, both in Brazil and in other countries, has been monitored mainly through two indicators. The first, called accumulated physical activity, uses information on the frequency and time spent on physical activity practices during the trip to school, physical education classes, and other extracurricular physical activities in the seven days prior to the survey ${ }^{10,11}$. This indicator is obtained by multiplying the frequency (days) by the duration (daily practice time) of said activity in each domain (trip to school, physical education class and extracurricular physical activities), followed by the sum of the three domains, which results in the total time of physical activity practice. The second indicator, called globally estimated physical activity (GEPA), is simpler and uses a single question to evaluate the daily practice of physical activity for at least 60 minutes in the 7 days prior to the survey ${ }^{10,11}$. In addition to its simplicity, another advantage of the GEPA is being used in health surveys, such as the Global School-based Student Health Survey (GSHS) ${ }^{12}$ and the 
Youth Risk Behavior Survey (YRBS) ${ }^{13}$, coordinated respectively by WHO and Centers for Disease Control and Prevention (CDC), allowing the comparison of the prevalence of physically active adolescents between countries.

The monitoring of risk factors and health protection - among them, physical activity - is important for the planning of public policies, especially in adolescents. In this sense, the National Adolescent School-based Health Survey (PeNSE) has, since 2009, collected information on important health aspects of Brazilian adolescents. However, there are still few studies that evaluate the practice of physical activity over time in adolescents living in large Brazilian urban centers, and the existing ones are usually local ${ }^{14}$ or assess specific contexts, such as the ways of traveling to school, which include active displacement (walking/ cycling during the home-school-home path $)^{15,16}$. In addition, after the $\mathrm{WHO}^{17}$ set a goal of reducing the number of inactive adolescents and adults by 10 percent by 2025 , monitoring of the practice of physical activity has become even more relevant, with recurrent assessments being required to check whether the goal or part of it has been reached, especially in urbanized areas that tend to present a lower level of physical activity compared to the rural ones $^{5}$. Finally, these results may help managers to evaluate and implement specific physical activity promotion policies for this age group.

Therefore, this study aimed to compare the prevalence of physically active adolescents residing in Brazilian capitals, investigated by the PeNSE 2012 and 2015 surveys.

\section{METHODS}

\section{SAMPLE AND DATA COLLECTION}

PeNSE is a cross-sectional, school-based survey that assesses health risk and protection factors for adolescents. This survey is part of the Surveillance System for Risk Factors for Noncommunicable Chronic Diseases and was conducted in 2009, 2012 and 2015, as the result of a partnership between the Health Surveillance Department of the Ministry of Health, the Ministry of Education and the Brazilian Institute of Geography and Statistics (IBGE). The sample was composed of students attending morning classes in the $9^{\text {th }}$ year of elementary school, in public and private schools, urban and rural areas, in 27 capitals and from a group of Brazilian countryside municipalities (PeNSE-2012 and PeNSE-2015). The choice of the 9th year of elementary school was based on WHO recommendations on the minimum schooling necessary to respond a self-administered questionnaire, and on the Child and Adolescent Statute ${ }^{18}$, which provides for the adolescent's autonomy in participating or not in questionnaires that do not offer health risks and that support public policies for health protection. It is also worth noting that, in the PeNSE questionnaire, an item was included in which adolescents are informed about the research and respond on their agreement to participate or not in the survey. 
The sample size of the present study was defined to include the 27 Brazilian capitals and allow analyzes of the GEPA indicator, first included in PeNSE-2012. Because it did not contain the GEPA indicator, PeNSE-2009 was not considered. Therefore, the analyzes of this study were performed with data referring to 61,145 (PeNSE-2012) ${ }^{10}$ and 51,192 (PeNSE$2015)^{11}$ adolescents. The sample was calculated for a maximum error of $3 \%$ in absolute value at a $95 \%$ confidence level. Additional details on the sampling process are available in previous publications ${ }^{10,11}$.

\section{CLASSIFICATION OF ADOLESCENTS ON THE PRACTICE OF PHYSICAL ACTIVITY}

The GEPA indicator was obtained through the following question in 2012: "In the last 7 days, on how many days did you practice physical activity for at least 60 minutes (one hour) per day? (add up all the time you spent on any type of physical activity), the options being: (a) None (0 day); (b) 1 day; (c) 2 days; (d) 3 days; (e) 4 days; (f) 5 days; (g) 6 days; (h) 7 days".

In 2015, the questions and response options were largely unchanged: "In the past 7 days, on how many days did you practice physical activity for at least 60 minutes ( 1 hour) a day? (Add up all the time you spent on any type of physical activity, on each day), with the response options being: (a) 0 days in the last 7 days ( 0 day); (b) 1 day in the last 7 days; (c) 2 days in the last 7 days; (d) 3 days in the last 7 days; (e) 4 days in the last 7 days; (f) 5 days in the last 7 days; (g) 5 days plus Saturday in the last 7 days; (h) 5 days plus Saturday and Sunday in the last 7 days".

Subsequently, the activity days were multiplied by the time of practice of said activity, which, in this case, was 60 minutes. From this information, adolescents were classified as physically active - those who practiced 300 or more minutes of physical activity per week and insufficiently active ( $<300$ minutes).

\section{DATA ANALYSIS}

Based on the criteria described above, the prevalences (in the form of proportions, in percentages) of physically active adolescents for each of the surveys (PeNSE-2012 and PeNSE-2015) were obtained, considering the 27 Brazilian capitals. Next, the prevalences were stratified by the following sociodemographic characteristics: gender (male and female); age range ( $\leq 13,14,15$ and $\geq 16$ years); maternal schooling - no schooling, incomplete/complete primary education ( 1 to 8 years of schooling), incomplete/complete secondary education (9 to 11 years of schooling) and incomplete/complete higher education (12+ years of schooling); skin color (white, black, yellow, brown, and indigenous); and by the 27 Brazilian capitals. For the comparison of the variables between the two surveys, descriptive statistics

were used, with analysis of the $95 \%$ confidence intervals $(95 \% \mathrm{CI})$. This method was used 
by Malta et al. ${ }^{19}$ to compare the prevalence of the main risk and protection factors for NCDs between PeNSE-2009 and PeNSE-2012.

In addition, in order to aid explanations, the percentage of adolescents with two or more physical education classes per week was compared between PeNSE-2012 and PeNSE- $2015^{8}$.

All analyzes were performed in Stata software version 12.0 (Stata Corporation, College Station, USA), taking into account the complexity of the sample design of each survey.

\section{ETHICAL ASPECTS}

All stages of the study were in accordance with the Declaration of Helsinki, with voluntary participation of the adolescents, and all information, both from the students and the schools, were kept confidential and unidentified. The National Research Ethics Commission approved the surveys for 2012 and 2015 (registrations no. 16.805 and no. 1.006.467, respectively) ${ }^{10,11}$.

\section{RESULTS}

The majority of the sample was composed of female adolescents in $2012(50.8 \%$ of girls) and 2015 (50.8\% of girls), aged between 14 and 15 years in both $2012(69.5 \%)$ and in 2015 (70.9\%) and with brown skin color, approximately $40 \%$ in both surveys. Regarding the years of maternal schooling, a reduction was observed in the percentage of students who knew the maternal schooling, with variation between 2012 (80.9\%) and 2015 (75.9\%). However, this loss of information was non-differential in the two surveys, considering the variables gender, age, tertile of goods and services and physical activity (data not shown).

As can be observed, there was no change in the prevalence of physically active adolescents between 2012 and 2015, respectively, $21.0 \%$ (95\%CI $20.3-21.7)$ and 20,7\% (95\%CI $20.1-21.3$ ) (Figure 1).

The maintenance of physical activity among schoolchildren was also verified regardless of gender, age, maternal schooling and skin color (Table 1).

When stratifying the prevalence of physically active adolescents by capitals, there was also a stabilization of physical activity practice, except in Belém, where there was a significant reduction in the prevalence of physically active adolescents from 2012 to 2015 (Figure 2).

It was also observed that, within the triennium analyzed, the percentage of adolescents with physical education classes in two or more days per week was maintained (Figure 3). 


\section{DISCUSSION}

The study showed that approximately one-fifth of the adolescents were considered physically active in the two editions of PeNSE (2012 and 2015), and there was no change in the prevalence of physically active individuals among schoolchildren living in the 27 Brazilian capitals during the study period. Maintenance was also identified in the practice of physical activity regardless of gender, age, maternal schooling and skin color. Among the capitals analyzed, a reduction in the prevalence of physically active adolescents was observed only in Belém.

This is the first study that portrays the maintenance of the prevalence of physically active schoolchildren, obtained by comparing PeNSE-2012 and PeNSE-2015. The GEPA indicator was chosen because it did not change in the two editions of PeNSE, which allows comparisons over time ${ }^{19}$. The current study also highlights the need to maintain standardized questions in large population surveys, which allows for more robust comparisons and analysis of temporal trends.

Another indicator used to measure the practice of physical activity in PeNSE 2012 and 2015 was accumulated physical activity, but the questions related to this indicator changed

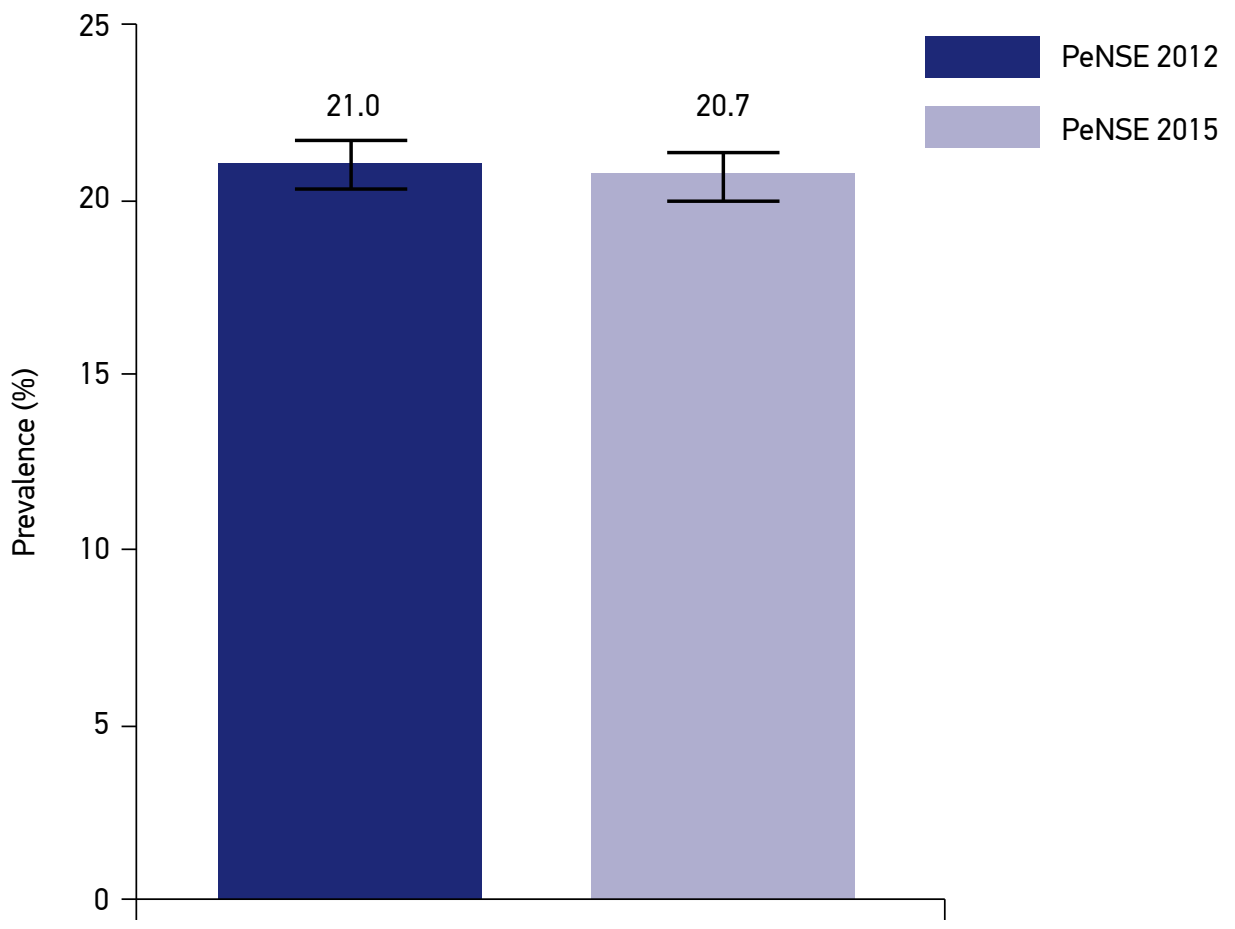

PeNSE: Pesquisa Nacional de Saúde do Escolar (National Adolescent School-based Health Survey). Source: data from the 2012 and 2015 National Adolescent School-based Health Survey.

Figure 1. Prevalence and $95 \%$ confidence intervals of physically active adolescents from the $9^{\text {th }}$ grade of elementary school, living in Brazilian capitals. 
between the two surveys $s^{20,21}$, limiting their comparison. In 2012, the trip to school domain was addressed in two questions, including the orientation for the adolescent to add the round trip times, while in 2015 there were four questions, with the round trip time being questioned separately.

The increase of two questions in 2012 to four questions in 2015 may have introduced an information bias, since between 2012 and 2015 there was an increase of $66.6 \%$ (unpublished data) in median travel time, a fact that did not occur in the other domains (physical education classes and physical extracurricular activities), whose questions were not changed in

Table 1. Prevalence of physically active adolescents from the $9^{\text {th }}$ grade of elementary school, residing in Brazilian capitals, according to sociodemographic characteristics.

\begin{tabular}{|c|c|c|c}
\hline & PeNSE 2012 & PeNSE 2015 & RC \\
\cline { 2 - 3 } & $\%(95 \% \mathrm{Cl})$ & $\%(95 \% \mathrm{Cl})$ & \multirow{2}{*}{$(\%)$}
\end{tabular}

\section{Gender}

\begin{tabular}{l|l|l|c}
\hline Male & $29.2(28.2-30.2)$ & $28.3(27.3-29.2)$ & -3.1 \\
\hline Female & $13.2(12.4-13.9)$ & $13.5(12.7-14.2)$ & 2.2 \\
\hline
\end{tabular}

Age (years)

\begin{tabular}{l|l|l|l}
\hline$\leq 13$ & $19.4(17.9-20.9)$ & $18.6(17.1-20.1)$ & -4.3 \\
\hline 14 & $20.7(19.7-21.6)$ & $20.1(19.2-21.0)$ & -2.6 \\
\hline 15 & $22.5(21.3-23.7)$ & $23.4(21.9-24.9)$ & 4.0 \\
\hline$\geq 16$ & $22.9(21.3-24.4)$ & $23.7(21.9-25.5)$ & 3.7 \\
\hline
\end{tabular}

Maternal schooling

\begin{tabular}{l|l|l|l}
\hline No schooling & $17.4(14.9-19.9)$ & $18.9(15.9-21.9)$ & 8.7 \\
\hline Primary education & $19.3(18.2-20.5)$ & $18.6(17.3-20.0)$ & -3.5 \\
\hline Secondary education & $20.4(19.3-21.5)$ & $20.8(19.7-21.9)$ & 2.0 \\
\hline Higher education & $26.5(24.9-28.0)$ & $23.8(22.6-24.9)$ & -10.1 \\
\hline Skin color & & & \\
\hline White & $21.7(20.6-22.9)$ & $20.3(19.3-21.3)$ & -6.7 \\
\hline Black & $22.2(20.6-23.7)$ & $22.4(20.5-24.2)$ & 0.9 \\
\hline Yellow & $19.9(17.2-22.5)$ & $21.8(18.6-24.9)$ & 9.7 \\
\hline Brown & $19.8(18.9-20.7)$ & $20.2(19.3-21.0)$ & 1.8 \\
\hline Indigenous & $24.1(20.8-27.3)$ & $24.6(21.6-27.6)$ & 2.2 \\
\hline
\end{tabular}

PeNSE: Pesquisa Nacional de Saúde do Escolar (National Adolescent School-based Health Survey); RC: relative change; $95 \% \mathrm{Cl}$ : 95\% confidence interval; $\mathrm{n}$ : sample.

Source: data from the 2012 and 2015 National Adolescent School-based Health Survey. 


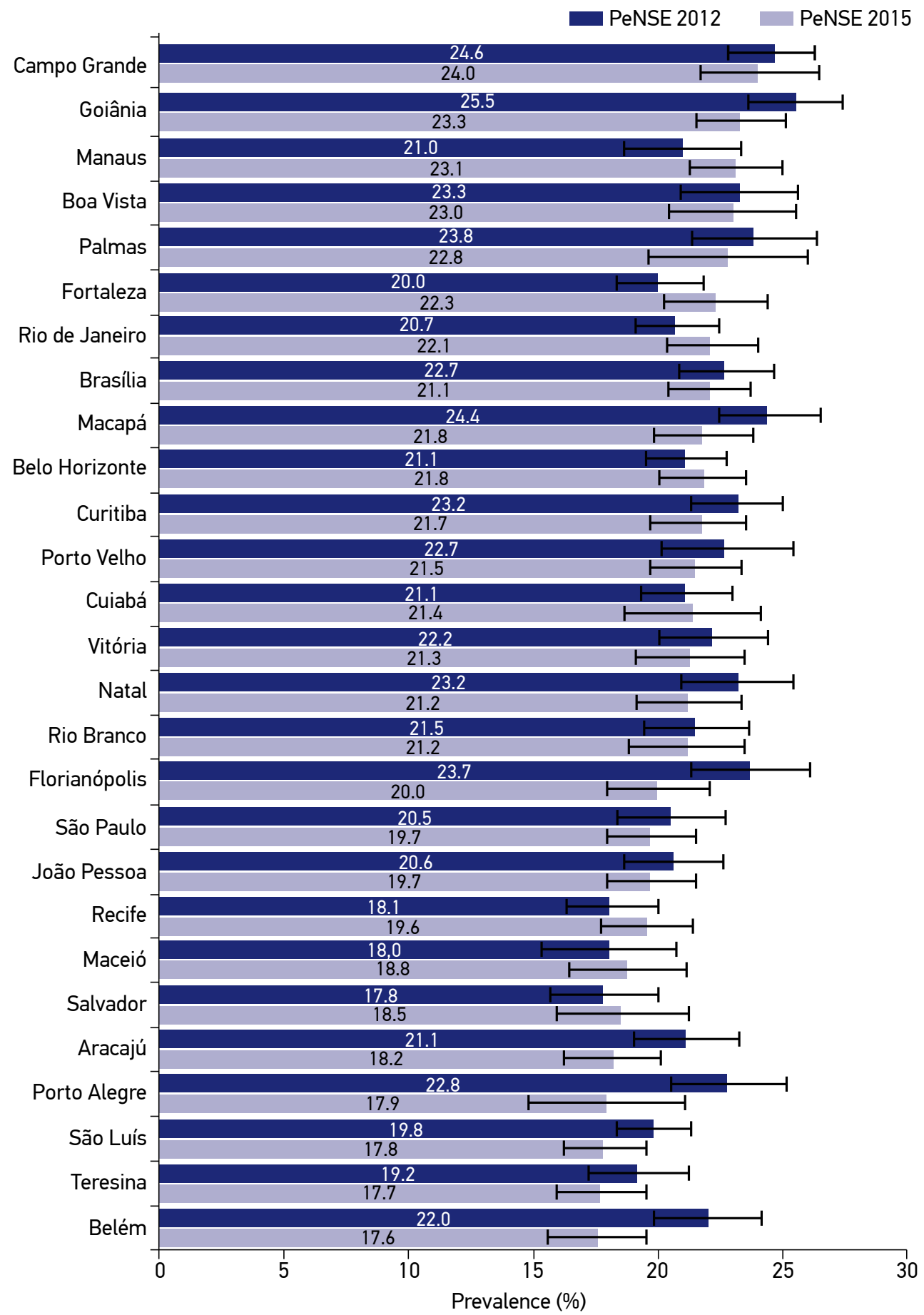

PeNSE: Pesquisa Nacional de Saúde do Escolar (National Adolescent School-based Health Survey).

Source: data from the 2012 and 2015 National Adolescent School-based Health Survey.

Figure 2. Prevalence and $95 \%$ confidence interval of physically active adolescents from the $9^{\text {th }}$ grade of elementary school, living in Brazilian capitals. 
the two editions of the survey ${ }^{20,21}$. Thus, the change in the prevalence of physically active adolescents from the 27 Brazilian capitals, using the accumulated physical activity indicator reported between PeNSE-2012 (33.0\%; 95\%CI 32.1 - 33.9 $)^{10}$ and PeNSE-2015 (36.3\%; 95\%CI $35.3-37.2)^{22}$ may be due to the modification of the questionnaires.

As a result of the problems presented previously with the accumulated physical activity indicator, the use of the GEPA indicator - which has also been used by the WHO and by US institutions such as the CDC to measure the practice of physical activity - makes it possible to compare the prevalence of physically active adolescents between countries ${ }^{10,11,23-26}$.

A brief comparison of the prevalence of physically active adolescents between countries shows that Brazilians have a higher level of physical activity than those in Ghana $(16.0 \%)^{23}$, similar to those in Malaysia $(21.7 \%)^{25}$ and lower than those in Argentina $(23.3 \%)^{26}$, Peru $(24.5 \%)^{27}$, Uruguay $(27.0 \%)^{28}$ and the United States $(48.6 \%)^{29}$, suggesting new studies to verify whether public policies to promote physical activity implemented in other countries in South and North America have been more assertive than the Brazilian ones.

In the United States, stabilization of physical activity in schoolchildren was also identified, although at much higher levels than in Brazil, 49.5\% in 2011 and $48.6 \%$ in $2015^{29}$. The maintenance of the prevalence of physically active adolescents becomes relevant when

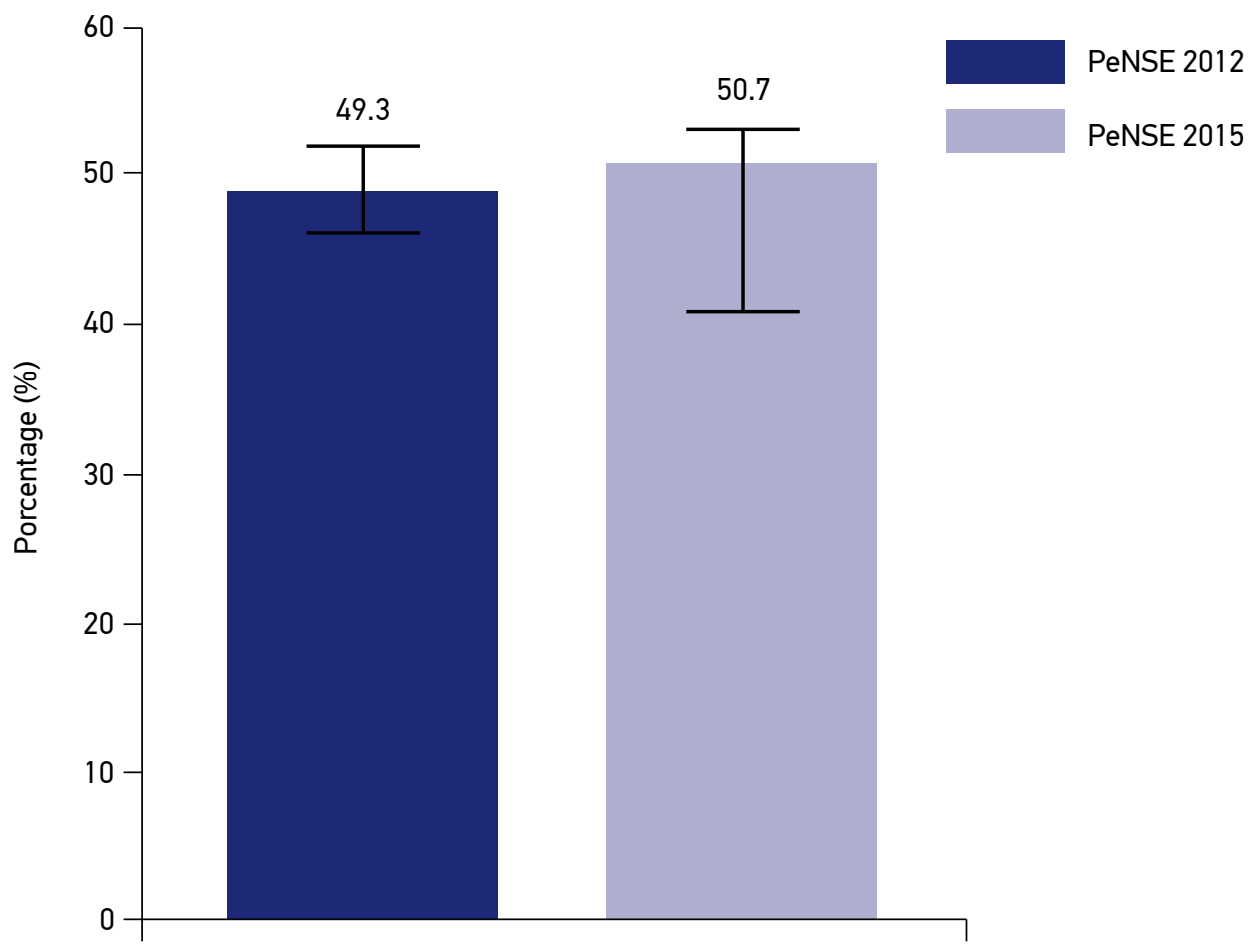

PeNSE: Pesquisa Nacional de Saúde do Escolar (National Adolescent School-based Health Survey).

Figure 3. Percentage and 95\% confidence interval of adolescents in the ninth grade of elementary school, living in Brazilian capitals, with physical education classes in two or more days per week. 
we compare these results with another study that indicates, in most countries, a decrease in the practice of physical activity by adolescents over time ${ }^{5}$. This reduction in the practice of physical activity can be explained by several factors, among them the inability to implement policies to promote physical activity on a large scale, as well as the rapid urbanization and easy access to motor vehicles ${ }^{5}$.

On the other hand, the present study shows that Brazil is far from WHO's goal of a $10 \%$ relative reduction in the prevalence of physical inactivity among adolescents and adults by $2025^{17}$, reinforcing the need to re-evaluate and/ or redirect existing public policies to generate an increase in the percentage of active young people, reducing future expenses with NCDs.

Brazil has invested in public policies to promote physical activity among adolescents. In this context, outdoor gyms, the School Health Program (PSE) and the Second Half Program (PST) can be highlighted. Oudoor gyms contemplate various physical activities and/or corporal practices that are developed with adolescents, adults and the elderly ${ }^{30,31}$, while the PSE promotes health in public schools through various actions, among which are food education and the stimulus to practice of physical activity through lectures and extracurricular activities, such as trekking and intercollegiate games, with the increase in the level of physical activity of students being one of the program's objectives ${ }^{32}$. On the other hand, PST, a public policy of the Ministry of Sports, understands sport as a duty of the State and as a right of all, seeking to reach children and adolescents in situations of social vulnerability and who are regularly enrolled and regularly attend school ${ }^{33}$.

Although an expansion has been reported in the three public policies cited above in the period between 2012 and $2015^{30-35}$, some considerations should be highlighted. In outdoor gyms, almost $100 \%$ of units reported developing activities with adults and the elderly, while only $76 \%$ were sought by adolescents ${ }^{30}$. In addition, $41.6 \%$ of the units reported difficulties in developing activities with adolescents, showing the need for investment and training of the teams to deal with the specifics of this age group and, consequently, to attract them to practice physical activity ${ }^{30}$. It is also possible that PST is positively influencing adolescents who already practice physical activity regularly. A study carried out in Africa showed that the development of sports activities with voluntary participation reaches those adolescents with greater physical capacity, not reaching the young people who need them most, that is, those who are not active enough ${ }^{36}$. It is also worth mentioning that more studies are needed to assess the capillarity of these public policies in urban centers, as well as to point out the possible barriers that make it difficult to include young people who are insufficiently active in these programs.

In addition to the counterpoints presented previously, the maintenance of physical education classes and violence was also observed, which are factors that may have contributed to the stability of physical activity practice ${ }^{7,37}$. Between PeNSE-2012 (49.3\%) and PeNSE2015 (50.7\%), there was no change in the percentage of adolescents who had physical education classes in two or more days of the week, and this may be one of the factors responsible for the maintenance of the prevalence of physically active adolescents in the triennium analyzed $^{7,38}$. These results are similar to those of Malta et al., who studied previous periods 
of the same survey, 2009 and $2012^{19}$, confirming that only half of adolescents have physical education classes in two or more days per week.

Extending physical education classes would be an essential action to raise the levels of practice of physical activity in this age group ${ }^{7}$. In addition, it is necessary to improve the spaces provided by schools for sports practice, as proposed by the strategic action plan for fighting $\mathrm{NCDs}^{39}$. Thus, students could benefit from the positive effects of regular physical activity, such as stagnation/reduction of the overweight and obesity epidemic, which affects approximately $25.5 \%$ of Brazilian adolescents ${ }^{40}$, and/or improvement in cognitive performance ${ }^{41}$.

The high rates of violence may also be one of the factors responsible for the non-expansion of the practice of physical activity in adolescents. According to the United Nations Development Program (UNDP), in Brazil, $24.7 \%$ of people have already restricted their leisure facility options due to fear of delinquency ${ }^{42}$, causing a negative impact on the practice of physical activity among adolescents and adults ${ }^{37,43}$. Thus, the similarity of homicide rates in Brazil between 2012 (29.4/ 100,000 inhabitants) and 2015 (28.9/ 100,000 inhabitants $)^{44}$, may be favoring the choice of activities with low caloric expenditure, such as watching television, playing video games and using computers ${ }^{45-47}$.

Among all the capitals analyzed, Belém was the only one that presented a reduction in the percentage of active adolescents. It is noteworthy that, in the state of Pará, there was an $8.7 \%$ increase in the homicide rate between 2012 (41.4/100,000 inhabitants) and 2015 $(45.0 / 100,000 \text { inhabitants })^{44}$. In addition, the capital, Belém, probably received less investment in infrastructure because it was not one of the venues of the 2014 FIFA World Cup, which may also have contributed to the reduction in physical activity practice ${ }^{5,48,49}$.

This study has some limitations and strengths. The questionnaire used to obtain the GEPA indicator is self-referenced, being subject to information bias. The use of accelerometers would provide objective and detailed measures of physical activity, but would not be practical in such a large sample. In addition, it has been reported that, during the evaluation of physical activity practice with questionnaires, one should avoid joining different physical activity domains, as it makes it difficult for respondents to remember the activities performed, increasing error in the measurement $t^{50,51}$. However, questions similar to the one used in the present study were compared with the accelerometry, providing a reliable estimate of the physical activity behavior of adolescents ${ }^{52,53}$. In addition, since the two surveys used the same question to evaluate the practice of physical activity, this limitation does not seem to interfere in the data comparison. Another limitation is the fact that only two points (prevalences) are evaluated in transversal panels, which can lead to instability in the evaluation of trends, requiring the maintenance of the surveys and the standardization of questions to allow longer comparisons.

Despite these limitations, this study uses data from a large-scale survey of adolescents from all Brazilian capitals, especially in the 14- and 15-year-old age groups, which guarantees their external validity. Thus, the results of this study can help to evaluate and elaborate public policies aimed at increasing the practice of physical activity among adolescents, contributing to the reduction of public health care spending with NCDs. 


\section{CONCLUSION}

It can be concluded that there was stability in the prevalence of physically active adolescents between 2012 and 2015, observed in all sociodemographic characteristics analyzed. Concurrently, the prevalence of $20.7 \%$ of physically active schoolchildren shows that it is necessary to continue evaluating existing public policies and developing new proposals that promote the practice of physical activity among adolescents.

In addition, PeNSE should be maintained and expanded, allowing for longer temporal analyzes and international comparability, contributing to the promotion of adolescent health.

\section{REFERENCES}

1. Archer T. Health benefits of physical exercise for children and adolescents. J Nov Physiother. 2014; 4(2): 2-5. https: / / doi.org/10.4172/2165-7025.1000203

2. Ekelund U, Brage S, Karsten F, Harro M, Anderssen $S$, Sardinha LB, et al. TV viewing and physical activity are independently associated with metabolic risk in children: The European youth heart study. PLoS Med. 2006; 3(12): 2449-57. https: / doi.org/10.1371/journal. pmed.0030488

3. Hallal PC, Victora CG, Azevedo MR, Wells JCK. Adolescent Physical Activity and Health: a Systematic Review. Sports Med. 2006; 36(12): 1019-30.

4. Hallal PC, Andersen LB, Bull FC, Guthold R, Haskell W, Ekelund U, et al. Global physical activity levels: surveillance progress, pitfalls, and prospects. Lancet. 2012; 380(9838): 247-57. https://doi.org/10.1016/ S0140-6736(12)60646-1

5. Sallis JF, Bull F, Guthold R, Heath GW, Inoue S, Kelly $\mathrm{P}$, et al. Progress in physical activity over the Olympic quadrennium. Lancet. 2016; 388(10051): 1325-36. https: / / doi.org/10.1016/S0140-6736(16)30581-5

6. World Health Organization. Global recommendations on physical activity for health. Genebra: WHO Library Cataloguing-in-Publication Data; 2010.

7. Rezende LFM, Azeredo CM, Canella DS, Claro RM, Castro IRR, Levy RB, et al. Sociodemographic and behavioral factors associated with physical activity in Brazilian adolescents. BMC Public Health. 2014; 14: 485. https: / / doi.org/10.1186/1471-2458-14-485

8. Hallal PC, Knuth AG, Cruz DKA, Mendes MI, Malta DC. Prática de atividade física em adolescentes brasileiros. Ciênc Saúde Coletiva. 2010; 15(2): 3035-42. http:// dx.doi.org/10.1590/S1413-81232010000800008
9. Ramos CGC, Andrade RG, Andrade ACS, Fernandes AP, Costa DAS, Xavier CC, et al. Contexto familiar e atividade física de adolescentes: cotejando diferenças. Rev Bras Epidemiol. 2017. http:/ / dx.doi. org/10.1590/1980-5497201700030015

10. Instituto Brasileiro de Geografia e Estatística. Pesquisa Nacional de Saúde do Escolar - 2012. Rio de Janeiro: IBGE; 2013.

11. Instituto Brasileiro de Geografia e Estatística. Pesquisa Nacional de Saúde do Escolar 2015. Rio de Janeiro: IBGE; 2016.

12. World Health Organization. Department of Chronic Diseases and Health Promotion. Global schoolbased student health survey (GSHS) purpose and methodology: 2013 core questionnaire modules [Internet]. Genebra: WHO, 2013 [citado em $28 \mathrm{dez}$. 2016]. Disponível em: http://www.who.int/chp/ gshs/GSHS_Core_Modules_2013_English.pdf

13. Centers for Disease Control and Prevention. Youth Risk Behavior Surveillance System (YRBSS) [Internet]. [citado em 15 jul. 2017]. Disponível em: https: / / www. cdc.gov/gshs/

14. Silva KS, Lopes Ada S, Hardman CM, Cabral LGA, Silva SG, Nahas MV. Commuting to school and to work among high school students in Santa Catarina state, Brazil: a comparative analysis between 2001 and 2011. J Phys Act Health. 2014; 11(8): 1458-67. https: / / doi.org/10.1123/jpah.2012-0410

15. Sá TH, Garcia LMT, Mielke GI, Rabacow FM, Rezende LFM. Changes in travel to school patterns among children and adolescents in the São Paulo Metropolitan Area, Brazil, 1997-2007. J Transport Health. 2015; 2(2): 143-50. https: / / doi.org/10.1016/j.jth.2015.02.008 
16. Reis RS, Salvo D, Ogilvie D, Lambert EV, Goenka S, Brownson RC, et al. Scaling up physical activity interventions worldwide: stepping up to larger and smarter approaches to get people moving. Lancet. 2016; 388(10051): 1337-48. https:// doi.org/10.1016/ S0140-6736(16)30728-0

17. World Health Organization. Global action plan for the prevention and control of noncommunicable diseases 2013-2020. Genebra: WHO Press; 2013.

18. Brasil. Lei $\mathrm{n}^{\circ} 8.069$, de julho de 1990. Dispõe sobre o Estatuto da Criança e do Adolescente e dá outras providências. Brasil: Câmara dos Deputados; 1990.

19. Malta DC, Andreazzi MAR, Oliveira-Campos M, Andrade SSCA, Sá NNB, Moura L, et al. Trend of the risk and protective factors of chronic diseases in adolescents, National Adolescent School-based Health Survey (PeNSE 2009 e 2012). Rev Bras Epidemiol. 2014; 17(1): 77-91.

20. Instituto Brasileiro de Geografia e Estatística. Pesquisa Nacional de Saúde do Escolar 2012 - Instrumentos de coleta: questionário do aluno [Internet]. [citado em 10 jan. 2017]. Disponível em: http:/ / biblioteca. ibge.gov.br/visualizacao/instrumentos_de_coleta/ doc2908.pdf

21. Instituto Brasileiro de Geografia e Estatística. Pesquisa Nacional de Saúde do Escolar 2015 - Microdados [Internet]. [citado em 10 jan. 2017]. Disponível em: http://www.ibge.gov.br/home/estatistica/populacao/ pense/2015/default_microdados.shtm

22. Instituto Brasileiro de Geografia e Estatística. Pesquisa Nacional de Saúde do Escolar 2015 - Resultados: Tabela 1.2.11.3 [Internet]. [citado em 10 jan. 2017]. Disponível em: http:/ /www.ibge.gov.br/home/ estatistica/populacao/pense/2015/default_xls.shtm

23. World Health Organization; Centers of Disease Control and Prevention. Global School-based Student Health Survey: Ghana Junior High 2012 Fact Sheet [Internet]. Atlanta: Centers for Disease Control and Prevention, 2013 [citado em 18 jul. 2017]. Disponível em: http:/ / www.who.int/chp/gshs/2012_Ghana_junior_high_ fact_sheet.pdf?ua=1

24. Kann L, Kinchen S, Shanklin SL, Flint KH, Kawkins J, Harris W, et al. Youth risk behavior surveillance United States, 2013. Morbidit and Mortality Weekly Report - Surveillance Summaries. Atlanta: Center for Disease Control and Prevention; 2014.

25. World Health Organization; Centers of Disease Control and Prevention. Global School-based Student Health Survey: Malaysia 2012 Fact Sheet [Internet]. Atlanta: Centers of Disease Control and Prevention, 2013 [citado em 18 jul. 2017]. Disponível em: http: / /www.who.int/chp/gshs/ Malaysia_2012_GSHS_FS_national.pdf
26. World Health Organization; Centers of Disease Control and Prevention. Global School-based Student Health Survey: Argentina (Cuidad de Buenos Aires) 2012 Fact Sheet [Internet]. Atlanta: Centers of Disease Control and Prevention, 2013 [citado em 18 jul. 2017]. Disponível em: http:/ / www.who.int/chp/gshs/Argentina_GSHS_ FS_2012_Cuidad_de_Buenos_Aires.pdf

27. World Health Organization; Centers of Disease Control and Prevention. Global School-based Student Health Survey: Peru 2010 Fact Sheet [Internet]. Atlanta: Centers of Disease Control and Prevention, 2011 [citado em 18 jul. 2017]. Disponível em: http://www.who.int/ chp/gshs/2010_GSHS_FS_Peru.pdf

28. World Health Organization; Centers of Disease Control and Prevention. Global School-based Student Health Survey: Uruguay 2012 Fact Sheet [Internet]. Atlanta: Centers of Disease Control and Prevention, 2013 [citado em 18 jul. 2017] Disponível em: http: / / www. who.int/chp/gshs/2012_Uruguay_GSHS_FS.pdf

29. Centers of Disease Control and Prevention. Trends in the Prevalence of Physical Activity and Sedentary Behaviors National YRBS: 1991-2015 [Internet]. Atlanta: Centers of Disease Control and Prevention; 2016 [citado em 18 jul. 2017]. Disponível em: https:/ / www.cdc.gov/healthyyouth/ data/yrbs/pdf/trends/2015_us_physical_trend_yrbs.pdf

30. Sá GBAR, Dornelles GC, Cruz KG, Amorim RCA, Andrade SSCA, Oliveira TP, et al. O Programa Academia da Saúde como estratégia de promoção da saúde e modos de vida saudáveis: cenário nacional de implementação. Ciênc Saúde Coletiva. 2016; 21(6): 1849-60. http:// dx.doi.org/10.1590/1413-81232015216.09562016

31. Simões EJ, Hallal PC, Pratt M, Ramos L, Munk M, Damascena W, et al. Effects of a community-based, professionally supervised intervention on physical activity levels among residents of Recife, Brazil. Am J Public Health. 2009; 99(1): 68-75. https://doi. org/10.2105/ AJPH.2008.141978

32. Brasil. Ministério da Saúde. Passo a passo PSE Programa Saúde na Escola; tecendo caminhos da intersetorialidade [Internet]. Brasília: Ministério da Saúde, 2011 [citado em 23 dez. 2016]. Disponível em: http:/ /bvsms.saude.gov.br/bvs/publicacoes/ passo_a_passo_programa_saude_escola.pdf

33. Brasil. Ministério do Esporte. Relatório de Gestão do Exercício 2014 [Internet]. Brasília: Ministério do Esporte, 2015 [citado em 17 dez. 2016]. Disponível em: http:/ / www.esporte.gov.br/arquivos/acessoInformacao/ auditorias/SE/2014/relatorioGestaoSE2014.pdf

34. Silva ACF. Programa Saúde na Escola: Análise da gestão local, ações de alimentação e nutrição e estado nutricional dos escolares brasileiros [tese]. São Paulo: Programa de Pós-Graduação em Nutrição e Saúde Pública da Universidade de São Paulo; 2014. 
35. Florindo AA, Reis RS, Farias Junior JCF, Siqueira FV, Nakamura PM, Hallal PC. Description of health promotion actions in brazilian cities that received funds to develop "Academia da Saúde" program. Rev Bras Cineantropom Desempenho Hum. 2016; 18(4): 483-92. http: / / dx.doi.org/10.5007/1980-0037.2016v18n4p483

36. Richards J, Foster C. Sport-for-development interventions: Whom do they reach and what is their potential for impact on physical and mental health in low-income countries? J Phys Activity Health. 2013; 10(7): 929-31.

37. Gordon-Larsen P, McMurray RG, Popkin BM. Determinants of adolescent physical activity and inactivity patterns. Pediatrics. 2000; 105(6): 83.

38. Soares CAM, Hallal PC. Interdependência entre a participação em aulas de Educação Física e níveis de atividade física de jovens brasileiros: estudo ecológico. Rev Bras Ativ Fís Saúde. 2015; 20(6): 588-97. http:// dx.doi.org/10.12820/rbafs.v.20n6p588

39. Brasil. Ministério da Saúde. Plano de ações estratégicas para o enfrentamento das doenças crônicas nãotransmissíveis (DCNT) no Brasil 2011-2022. Brasília: Ministério da Saúde; 2011.

40. Bloch KV, Klein CH, Szklo M, Kuschnir MCC, Abreu GA, Barufaldi LA, et al. ERICA: Prevalences of hypertension and obesity in Brazilian adolescents. Rev Saúde Pública. 2016; 50(1): 1-12. http://dx.doi. org/10.1590/s01518-8787.2016050006685

41. Sardinha LB, Marques A, Martins S, Palmeira A, Minderico C. Fitness, fatness, and academic performance in seventhgrade elementary school students. BMC Pediatr. 2014; 14: 176. https: / / doi.org/10.1186/1471-2431-14-176

42. Programa das Nações Unidas para o Desenvolvimento. Relatório Regional de Desenvolvimento Humano 20132014: Segurança Cidadã com rosto humano: Diagnóstico e Propostas para a América Latina [Internet]. Nova York: PBM Graphics; 2013. [citado em 27 maio 2017]. Disponível em: http: / /www.pg.undp.org/content/ $\mathrm{dam} / \mathrm{rblac} / \mathrm{docs} /$ Research\%20and\%20Publications/ IDH/UNDP-RBLAC-ResumoExecPt-2014.pdf

43. Reis RS, Yan Y, Parra DC, Brownson RC. Assessing Participation in Community-Based Physical Activity Programs in Brazil. Med Sci Sports Exerc. 2014; 46(1): 92-8. https: / doi.org/10.1249/MSS.0b013e3182a365ae

44. Cerqueira D, Lima RS, Bueno S, Valencia LI, Hanashiro O, Machado PHG, et al. Atlas da Violência 2017 [Internet]. Rio de Janeiro: IPEA; 2017 [citado em 28 jul. 2017]. Disponível em: http:/ / www.ipea.gov.br/ portal/images/170609_atlas_da_violencia_2017.pdf
45. Seabra AF, Mendonça DM, Thomis MA, Anjos LA, Maia JA. Determinantes biológicos e sócio-culturais associados à prática de atividade física de adolescentes. Cad Saúde Pública. 2008; 24(4): 721-36. http: / / dx.doi. org/10.1590/S0102-311X2008000400002

46. Gomez LF, Sarmiento R, Ordoñez MF, Pardo CF, Sá TH, Mallarino $\mathrm{CH}$, et al. Urban environment interventions linked to the promotion of physical activity. A mixed methods study applied to the urban context of Latin America. Soc Sci Med. 2015; 131 (40): 18-30. https:/ / doi.org/10.1016/j.socscimed.2015.02.042

47. Andrade L, Braga Filho H. A interiorização da violência social: uma análise do interior paulista. Desenv Regional Debate. 2016; 6(1): 192-217. http:/ / dx.doi. org/10.24302/drd.v6i1.934

48. Mota J, Almeida M, Santos R, Ribeiro JC, Santos MP. Association of perceived environmental characteristics and participation in organized and non-organized physical activities of adolescents. Pediatr Exerc Sci. 2009; 21(2): 233-9.

49. Sallis JF, Cain KL, Conway TL, Gavand KA, Millstein RA, Geremia CM, et al. Is Your Neighborhood Designed to Support Physical Activity? A Brief Streetscape Audit Tool. Preventing Chronic Disease. 2015; 12: 141. http: / / dx.doi.org/10.5888/pcd12.150098

50. Ainsworth BE, Caspersen CJ, Matthews CE, Mâsse LC, Baranowski T, Zhu W. Recommendations to improve the accuracy of estimates of physical activity derived from self report. J Phys Act Health. 2012; 9(1): S76-84.

51. Finger JD, Gisle L, Mimilidis H, Santos-Hoevener C, Kruusmaa EK, Matsi A, et al. How well do physical activity questions perform? A European cognitive testing study. Arch Public Health. 2015; 73: 57. https: / / doi.org/10.1186/s13690-015-0109-5

52. Prochaska JJ, Sallis JF, Long B. Validity \& reliability of physical activity screening tools for adolescents in primary care settings. Arch Pediatr Adolesc Med. 2001; 155(5): 554-9.

53. Liu Y, Wang M, Tynjälä J, Lv Y, Villberg J, Zhang $Z$, et al. Test-retest reliability of selected items of Health Behaviour in School-aged Children (HBSC) survey questionnaire in Beijing, China. BMC Med Res Methodol. 2010; 10: 73. https://dx.doi. org/ 10.1186\%2F1471-2288-10-73

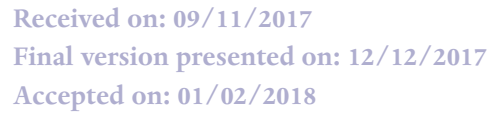

